\title{
O ESTADO DA ARTE DAS PRÁTICAS DIDÁTICO-PEDAGÓGICAS EM EDUCAÇÃO AMBIENTAL (PERÍODO DE 2010 A 2017) NA REVISTA BRASILEIRA DE EDUCAÇÃO AMBIENTAL
}

\author{
Gabrielle Silva Rodrigues ${ }^{1}$ \\ Benjamin Carvalho Teixeira Pinto ${ }^{2}$ \\ Lana Claudia de Souza Fonseca ${ }^{3}$ \\ Cristiana do Couto Miranda ${ }^{4}$
}

Resumo: No cenário político, econômico e social, uma temática em relevância é o meio ambiente. Entretanto, a temática apresenta muitas discussões epistemológicas inseridas no campo teórico e há uma escassez de propostas e reflexões práticas. Essas, quando ocorrem, persistem em abordagens conservadoras em Educação Ambiental. Este trabalho, baseado em pesquisa do estado da arte, expõe um panorama das práticas didático-pedagógicas em Educação Ambiental nas publicações da Revista Brasileira de Educação Ambiental (RevBEA), no período de 2010 a 2017. Foi identificado que as práticas didático-pedagógicas em Educação Ambiental têm alcançado alguns objetivos defendidos por autores da área, mas ainda carece de uma discussão entre teoria e prática em busca de uma Educação Ambiental Crítica.

Palavras-chave: Meio Ambiente; Práticas Didático-Pedagógicas; Estado da Arte.

${ }^{1}$ Universidade Federal Rural do Rio de Janeiro. E-mail: gabrielle.s.rodrigues@hotmail.com.

2 Universidade Federal Rural do Rio de Janeiro. E-mail: benjamin@ufrrj.br.

3 Universidade Federal Rural do Rio de Janeiro. E-mail: lanaclaudiafonseca@gmail.com.

${ }^{4}$ Instituto Federal do Rio de Janeiro. E-mail: cristiana.miranda@ifrj.edu.br. 


\section{Introdução}

Os diferentes impactos ambientais ocorrem, principalmente, em função do tipo de relação que o ser humano estabelece com o meio ambiente. Ao longo de sua evolução, enquanto espécie biológica, o homem desenvolveu sua organização social e, junto a ela, estabeleceu seu relacionamento com a natureza (PELICIONI; PHILIPPI, 2005; FEITOSA, 2014) gerando problemas ambientais e sociais que se intensificam com a expansão da economia e do capitalismo. Nesse cenário, a preocupação com os problemas socioambientais tem se tornado cada vez mais frequente, principalmente, a partir dos anos setenta, do século XX, no momento em que a questão ambiental passou a ser discutida em âmbito mundial, muito por pressão da sociedade e dos movimentos sociais. Assim, há uma crescente produção acadêmica dentro do campo da Educação Ambiental, o que a faz expandir e se consolidar como uma importante área de conhecimento.

No Brasil, o processo de institucionalização da Educação Ambiental teve início em 1973, com a criação da Secretaria Especial do Meio Ambiente (SEMA), que, em suas propostas e práticas nos setores educacionais, confundiam a Educação Ambiental com aulas de ecologia (DIAS, 2000). No entanto, o pensamento de Educação Ambiental como estudo de conceitos e fenômenos da ecologia, foge ao proposto como Educação Ambiental. O pensamento "ecologista" é refletido em algumas macrotendências da Educação Ambiental, como a conservacionista, e muito se aplicam em práticas pedagógicas na Educação Ambiental nas escolas até hoje. Essas atividades relacionam-se com propostas de Educação Ambiental que proporcionam um contato com a natureza, mas estão distanciadas das dinâmicas sociais e políticas que compõem as questões ambientais (LOUREIRO; LAYRARGUES, 2013).

A macrotendência chamada de ecoeficiência ou pragmática (ALIER, 2014; LOUREIRO; LAYRARGUES, 2013) também segue essa lógica ecológica e naturalista, porém traz para prática em Educação Ambiental a ideia de mecanismos de compensação para corrigir a 'imperfeição' do consumismo, mantendo, dessa maneira, a viabilidade do modelo de acumulação do capital, sem discutir que esses processos capitalistas são aqueles responsáveis pela própria crise ambiental.

Nessa perspectiva de avanços epistemológicos da Educação Ambiental, surge uma perspectiva mais crítica e mais consoante com uma proposta de educação transformadora, construtivista e emancipatória. Inicia-se paralelo com as outras macrotendências (tradicional e da ecoeficiência), em nosso país, após o período de ditadura, esse novo modelo de discussão e abordagem crítica, a partir da segunda metade dos anos 90, com a implementação de diretrizes e políticas públicas, com o processo de redemocratização da sociedade brasileira e o fortalecimento de perspectivas críticas na educação. Crescendo, então, a promoção e estimulo às atividades práticas em Educação Ambiental, passando por um "boom" (REIGOTA, 2017; DIAS et al., 2016). Contudo, não necessariamente esse maior fluxo de

Revbea, São Paulo, V. 14, № 1: 09-28, 2019. 
atividades de práticas em Educação Ambiental tem uma abordagem crítica, como aponta a pesquisa do Ministério da Educação, de 2004, que evidenciou que muitas escolas realizam práticas didático-pedagógicas em Educação Ambiental impregnadas de contradições (MELLO; TRAJBER, 2007).

Dessa forma, apesar da consolidação do campo da Educação Ambiental, há uma necessidade de amadurecimento teórico e metodológico desse modelo de Educação, e as práticas devem refletir o amplo campo teórico desse modelo. O campo teórico vem se mostrando ligado a uma perspectiva mais crítica, percebendo o indivíduo como elemento de atuação e transformação no meio ambiente e na sociedade (PEDRINI; SAITO, 2014). Entretanto, as propostas de atividades práticas não acompanham a teoria epistemológica produzida pelos teóricos da Educação Ambiental Crítica.

Com base nessas premissas, a pesquisa teve como objetivo realizar um levantamento da produção acadêmica nos estudos de Educação Ambiental para avaliar o que vem sendo desenvolvido sobre práticas didáticopedagógicas nessa área de conhecimento, no período de 2010 a 2017, à luz da metodologia do Estado da Arte, a fim de elucidar diretrizes para pesquisas e reflexões teórico-metodológicas, apontando para um panorama acerca das questões que exigem atenção.

\section{Metodologia}

O trabalho caracteriza-se como uma pesquisa bibliográfica do tipo Estado da Arte, com abordagem qualitativa, embasado no trabalho de revisão bibliográfica sobre Estado da Arte de Souza e Nascimento Jr. (2014). Os artigos foram analisados, inicialmente, com uma leitura flutuante, atividade que objetivou gerar impressões iniciais acerca do material a ser analisado. Em um segundo momento foi destacado e classificado os artigos conforme tópicos seguidos pelo método do Estado da Arte.

Entre os autores (LORENZETTI; DELIZOICOV, 2006; VASCO; ZAKRZEVSKI, 2010; MANCINI; KAWASAKI, 2013; ALVES, 2016) que desenvolveram pesquisas do tipo Estado da Arte em Educação Ambiental, utilizou-se o estudo de Reigota (2002), de forma adaptada para atender ao material analisado neste trabalho, que diferem por serem artigos (Revista Brasileira de Educação Ambiental (RevBEA)) e não teses de programas de pós-graduação, sendo os seguintes itens implementados: 1) No título, palavraschave ou resumo os termos "educação ambiental", "meio ambiente", "ensino", "práticas pedagógicas" ou similares; 2) artigos publicados em revista com temática ambiental; 3 ) discussões sobre temas educacionais e ambientais em diversas áreas do conhecimento.

Para classificar os trabalhos dentro de práticas pedagógicas também se utilizou os critérios criados por Reigota (2002): a) Relações com o espaço disciplinar: classificação dos trabalhos conforme o espaço em que a prática foi desenvolvida - espaços formais ou espaços não formais de educação; b) Fundamentos teóricos: classificação dos trabalhos quanto aos aspectos de

revista brasileira educação ambiental 
macrotendências em Educação Ambiental, conforme a classificação de Loureiro e Layrargues (2013) que ressaltam e definem três principais macrotendências - a Conservacionista, Pragmática e Crítica; c) As instituições educativas: os níveis educativos, escola básica, ensino superior e outros espaços, que são privilegiados na atuação das propostas e ações práticas em Educação Ambiental; d) Metodologias: os métodos utilizados na implementação das práticas, classificados nas categorias - materiais didáticos, aulas práticas, projetos, oficina, sequências didáticas, trilhas ecológicas, tema gerador e uso de tecnologias; e) Grupos sociais: para quem a prática está direcionada, isto é, se são para grupo de estudantes, grupos de professores em formação ou grupos diversificados.

Em estudos de Estado da Arte, realizam-se importantes comparações sobre as mudanças nos cenários da construção da área de conhecimento pesquisada. Assim, na pesquisa, buscaram-se referências bibliográficas que abordassem acerca da temática - práticas pedagógicas - em Educação Ambiental. Contudo, não foram encontrados trabalhos com a referida temática que permitisse comparação. $O$ trabalho que mais se aproximou foi o estudo realizado por Reigota (2002), que destacou algumas características pedagógicas, como o tipo de público e os tipos de temas ambientais mais encontrados. Desse modo, na pesquisa, também compararam-se esses dados, se permaneceram ou foram modificados no recorte do tempo pesquisado.

A pesquisa foi desenvolvida de forma manual, com base em todos os artigos publicados online pela Revista Brasileira de Educação Ambiental (RevBEA $)^{5}$. Utilizou-se a Plataforma Lattes, disponível em: http://lattes.cnpq.br/, na procura de currículos, para classificar a área de atuação dos autores dos artigos investigados. O grau de formação acadêmico mais elevado dos autores foi o considerado.

Nos últimos anos, há uma expansão acentuada da produção acadêmica, criação de programas, seminários, encontros, um interesse cada vez mais crescente de pesquisas e intensificação de publicações. Essa expansão na produção levanta reflexões, questionamentos e hipóteses sobre: Quais são os temas que recebem mais atenção? Como os temas têm sido abordados? Quais contribuições e pertinência destas publicações para a área? Para responder as indagações são necessários estudos que realizem um balanço e um mapeamento que desvende e examine o conhecimento já elaborado e apontem os enfoques, os temas mais pesquisados e as lacunas existentes (ROMANOWSKI; ENS, 2006).

A pesquisa bibliográfica do tipo Estado da Arte ou Estado do Conhecimento possui esse caráter de mapear e discutir determinada produção acadêmica em diferentes áreas do conhecimento. Possui natureza catalográfica e descritiva da produção acadêmica acerca do assunto de

\footnotetext{
${ }^{5}$ Revista disponível em: http://www.sbecotur.org.br/revbea, no período de 2010 a 2017. O
} período escolhido se deveu a disponibilidade online da revista.

Revbea, São Paulo, V. 14, № 1: 09-28, 2019. 
interesse e suas transformações ao longo de um período delimitado da história da construção da área do conhecimento investigada (LORENZETII; DELIZOICOV, 2006). Diferente da pesquisa bibliográfica comum que visa à pesquisa de informações em um amplo alcance e a utilização de dados dispersos em inúmeras publicações para a construção de um quadro conceitual (LIMA; MIOTO, 2007). Segundo Soares e Maciel (2000, p. 04), em um trabalho do tipo Estado da Arte é necessário considerar "categorias que identifiquem, em cada texto, e no conjunto deles as facetas sobre as quais o fenômeno vem sendo analisado". Então, a metodologia do Estado da Arte não se restringe a identificar a produção, mas analisá-la, categorizá-la e revelar os múltiplos enfoques.

Ferreira (2002), afirma que durante os últimos quinze anos ocorreu a elaboração de um conjunto significativo das investigações do tipo Estado da Arte. Esse movimento foi motivado pela sensação de não conhecimento acerca da totalidade de estudos e pesquisas em determinada área, consequência do crescimento quantitativo e qualitativo e da pouca divulgação sobre uma certa produção acadêmica.

Outrossim, foi realizada a análise dos artigos encontrados e com esses dados foi construído um banco de dados, sistematizando na forma de gráficos e tabelas as informações coletadas.

\section{Resultados e Discussões}

Foram encontrados e analisados 645 artigos, dentre todas as edições disponibilizadas online da Revista Brasileira de Educação Ambiental de 2010 até novembro de 2017. Desse total, $75 \%$ dos artigos eram trabalhos teóricos e 25\% (163 artigos) eram trabalhos contendo práticas pedagógicas (Figura 1).

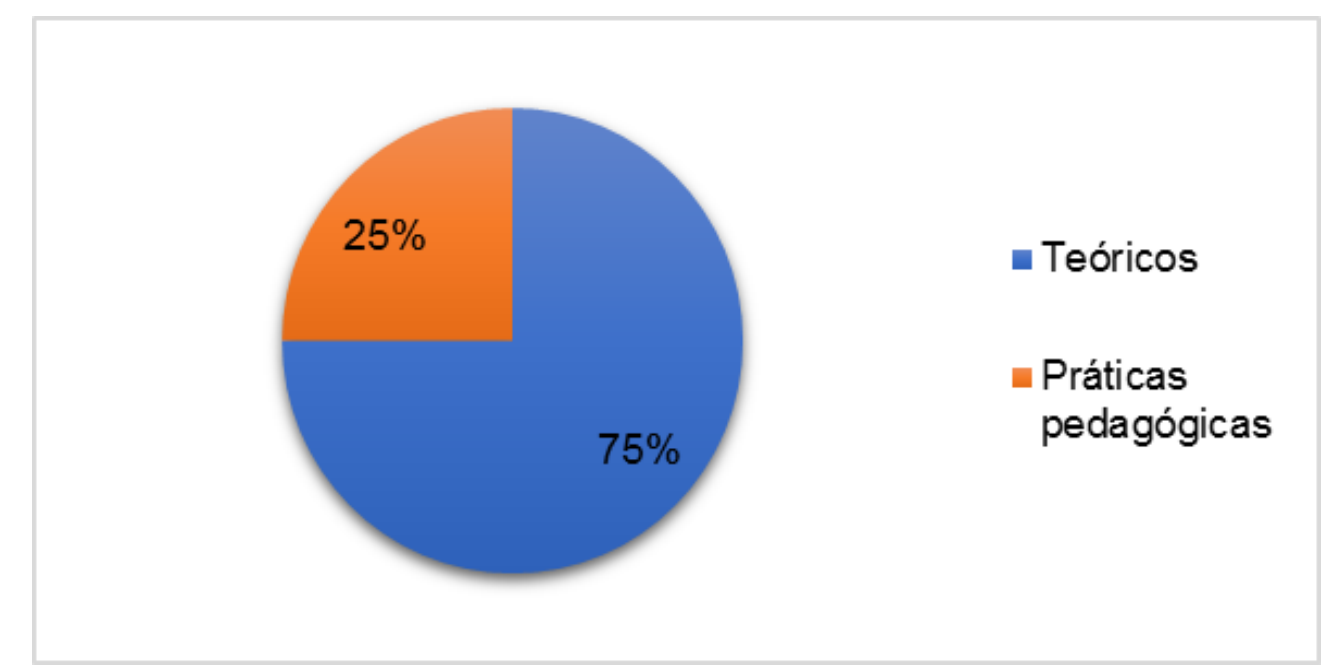

Figura 1: Frequência de artigos publicados na Revista Brasileira de Educação Ambiental quanto ao tipo de trabalho no período de 2010 a 2017. Fonte: autoria própria. 
Observa-se, no estudo, que o campo da Educação Ambiental se apresenta por meio de uma grande reflexão teórica, expressa na grande quantidade de trabalhos que refletem conceitos, relações epistemológicas, avanços metodológicos e diferentes perspectivas teóricas da área.

Além disto, a maior produção de artigos em práticas pedagógicas em Educação Ambiental entre 2010 e 2017, publicados na revista RevBEA, foram nas áreas de Ciências Humanas, com 45 trabalhos (27,6\%), seguido pelas Ciências Biológicas, com 41 trabalhos $(25,1 \%)$ e na área Multidisciplinar, que inclui as Ciências Ambientais, com 41 trabalhos (25,1\%), conforme apresentado na Figura 2. Os menores números foram encontrados na área de Ciências Exatas e da Terra e de Letras e Artes. Sobre esse contexto, as Diretrizes Curriculares Nacionais para a Educação Ambiental, estabelecem no capítulo II, que um dos objetivos da Educação Ambiental é a "abordagem curricular integrada e transversal, contínua e permanente em todas as áreas de conhecimento, componentes curriculares e atividades escolares e acadêmicas" (BRASIL, 2012, p. 4). Deste modo, seria imprescindível que todas as áreas do conhecimento desenvolvessem atividades em Educação Ambiental. Para justificar a baixa produção, por exemplo, nas Ciências Exatas, Pereira et al. (2016) sinalizam que uma das dificuldades em encontrar a Educação Ambiental na área de ensino de física está atrelada à formação docente, uma vez que muitos cursos de licenciatura na área das Ciências Exatas não incorporam na grade curricular discussões ambientais.

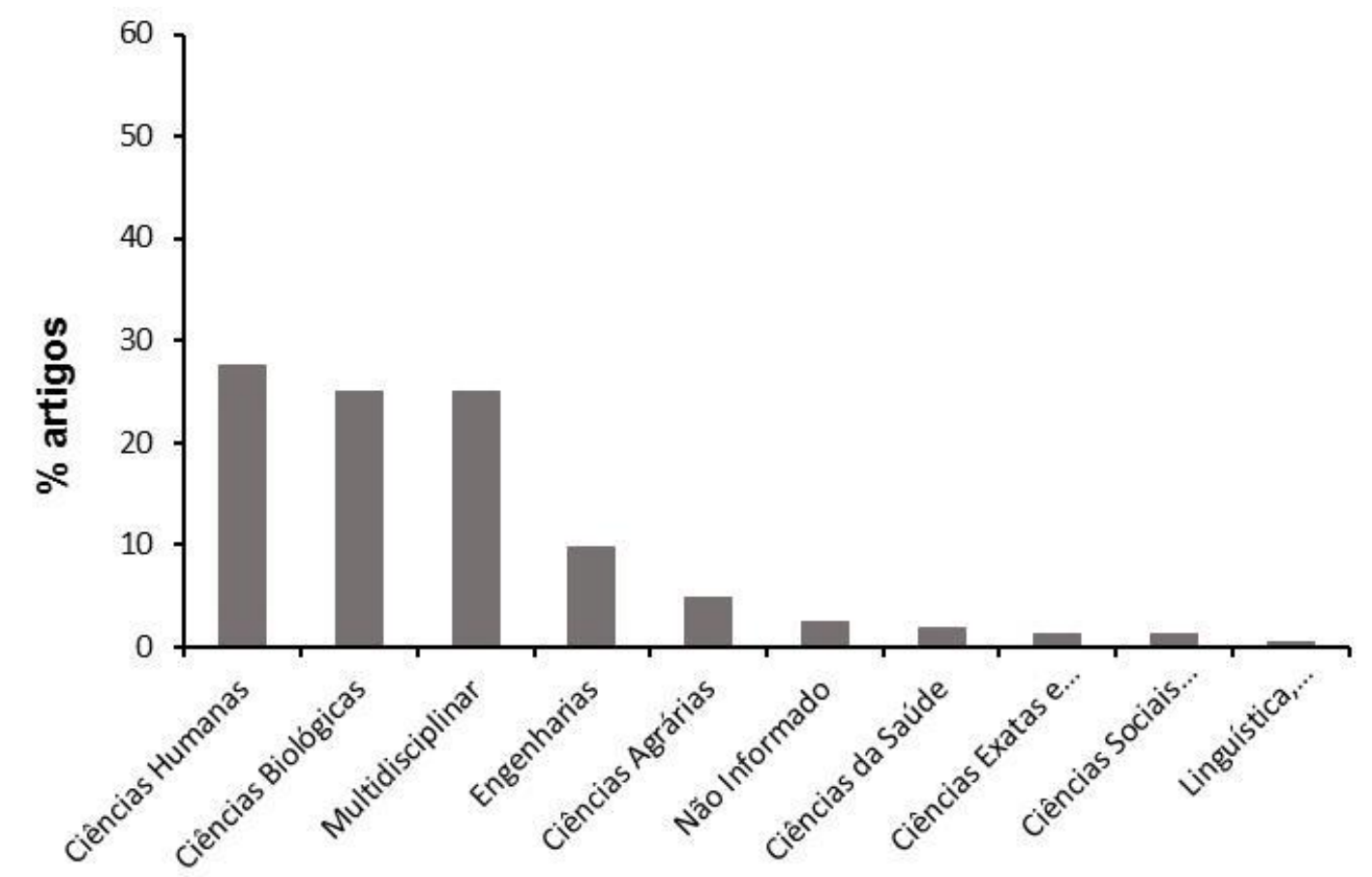

Figura 2: Produção sobre tema "Práticas pedagógicas em Educação Ambiental" de acordo com as Grandes Áreas do Conhecimento dos autores no período de 2010 a 2017.

Fonte: autoria própria. 
Conforme a Figura 3, a produção com práticas pedagógicas, em relação ao ano de publicação, foi maior em 2017, com 58 artigos, seguido do ano de 2014, com 36 artigos. Em 2014 foram publicados pela revista os anais do 8ํㅜ Fórum Brasileiro de Educação Ambiental e em 2017 os anais do 9o Fórum Brasileiro e o 4ํㅡㄹ Encontro Catarinense de Educação Ambiental, o que pode justificar o maior volume de artigos com propostas de práticas pedagógicas encontrados nestes anos. Pode-se concluir que esses fóruns propiciaram acesso maior à divulgação científica de autores locais, impulsionando publicações mais variadas indicando a maior facilidade de encontrar trabalhos com abordagens práticas educativas nesses eventos.

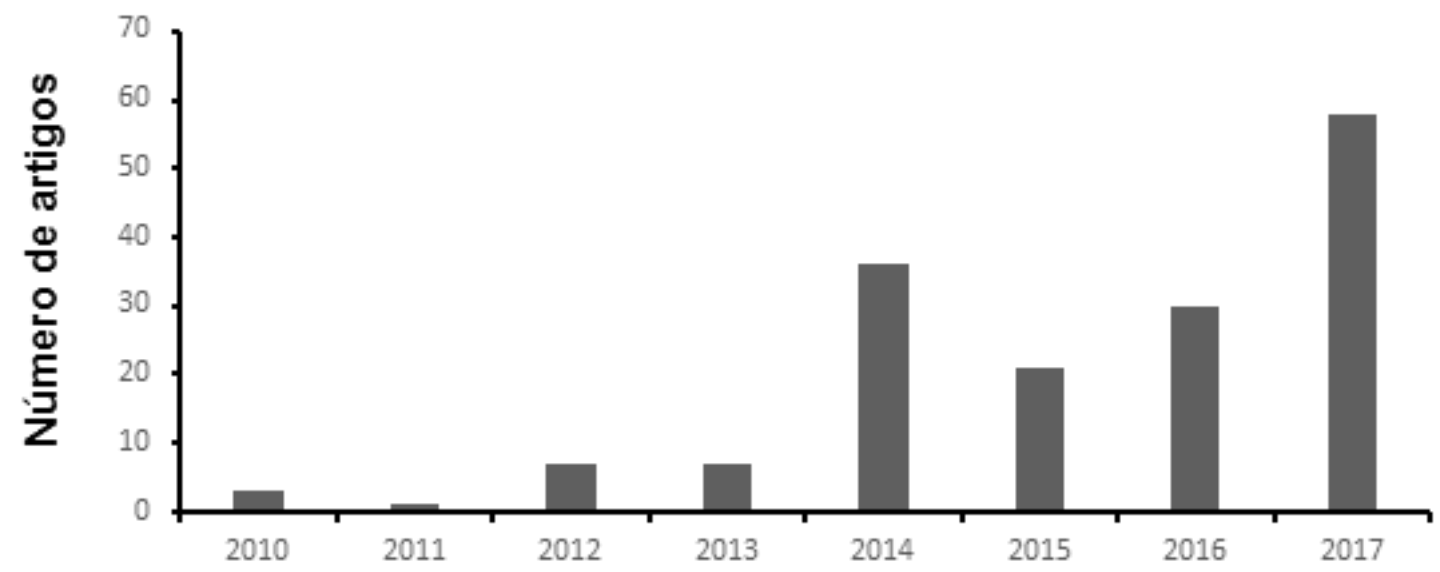

Figura 3: Quantidade de artigos por ano de publicação sobre Práticas Pedagógicas em Educação Ambiental, entre 2010 a 2017. Fonte: autoria própria.

Quanto à distribuição das produções pelas unidades federativas do Brasil, de acordo com a figura 4, Santa Catarina e Pará foram os estados que apresentaram as maiores quantidades de artigos, com 23 trabalhos cada estado, seguido por São Paulo com 17 trabalhos, e Paraná, com 15 trabalhos.

Visto que Santa Catarina e Pará foram os estados que mais publicaram artigos da temática (Figura 4), os dados revelam algo contrário ao que se pode supor, já que os estados com maior recurso e que se concentram os centros de pesquisa encontram-se nos estados da região sudeste, que tiveram menor número de produções na área. O maior número de artigos publicados no estado de Santa Catarina e no Pará, respectivamente, pode ter sido influenciado pelo fato que o $8^{\circ}$ Fórum foi realizado na Universidade Federal do Pará, em Belém/PA e o 9ำ Fórum foi realizado na Universidade do Vale do Itajaí, em Balneário Camboriú/SC, promovendo o encontro e publicação de autores locais. 


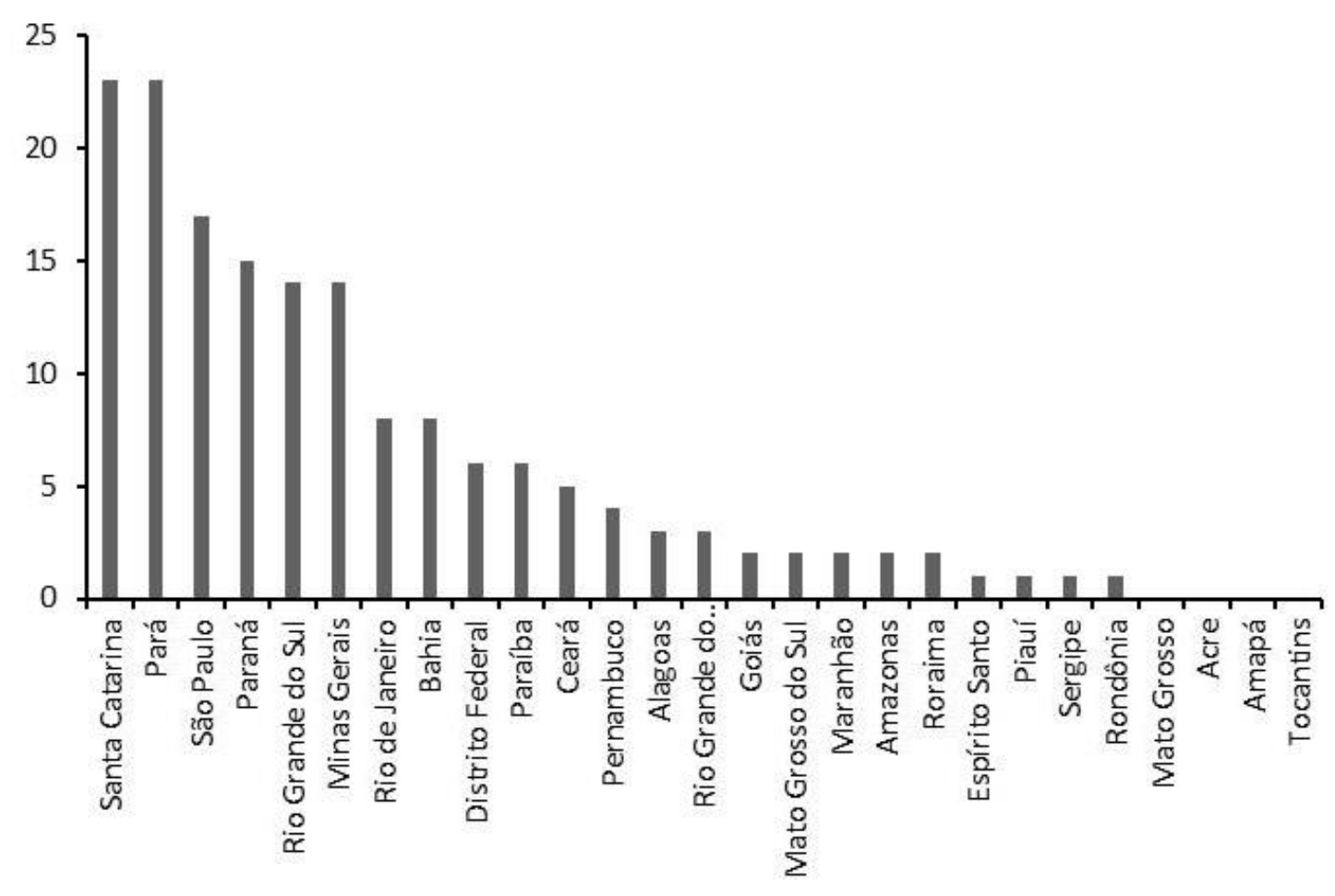

Figura 4: Distribuição de número de artigos por unidade federativa sobre Práticas Pedagógicas em Educação Ambiental, entre 2010 a 2017. Fonte: autoria própria.

Convém enfatizar que a região Sudeste foi a segunda região brasileira a publicar o maior número de artigos envolvendo práticas pedagógicas, apresentando 40 trabalhos, conforme as figuras 5 e 6 . A menor produção é da região Centro-oeste (Figuras 5 e 6 ).

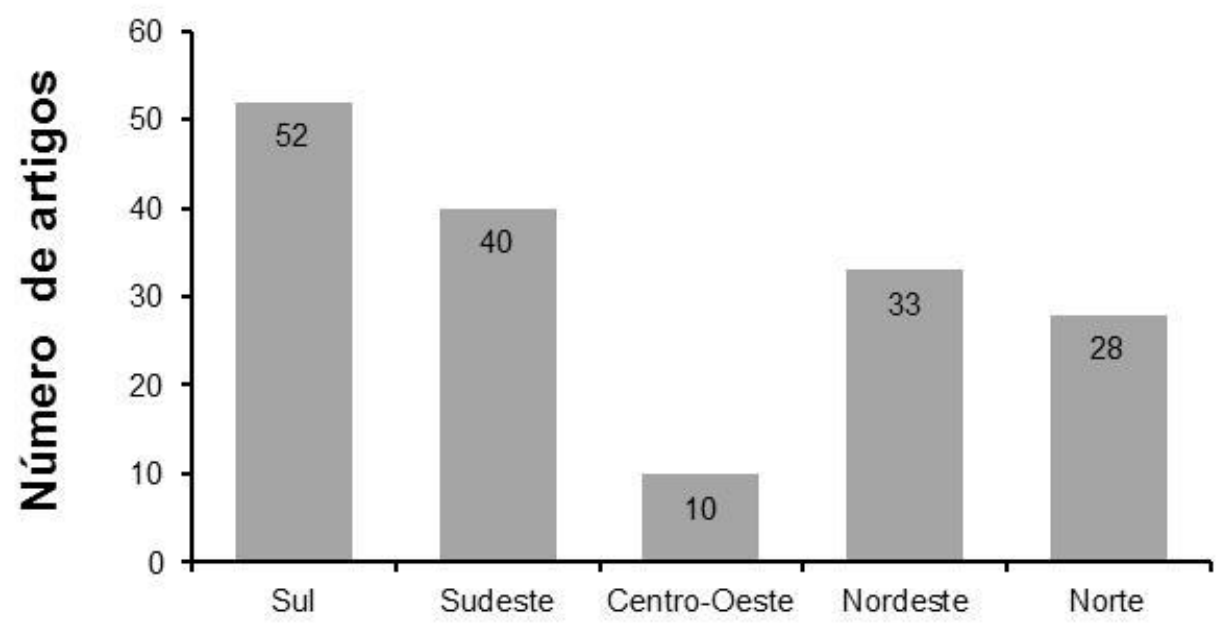

Figura 5: Distribuição de artigos por regiões geográficas brasileiras sobre Práticas Pedagógicas em Educação Ambiental, entre 2010 a 2017. Fonte: autoria própria.

Revbea, São Paulo, V. 14, № 1: 09-28, 2019. 


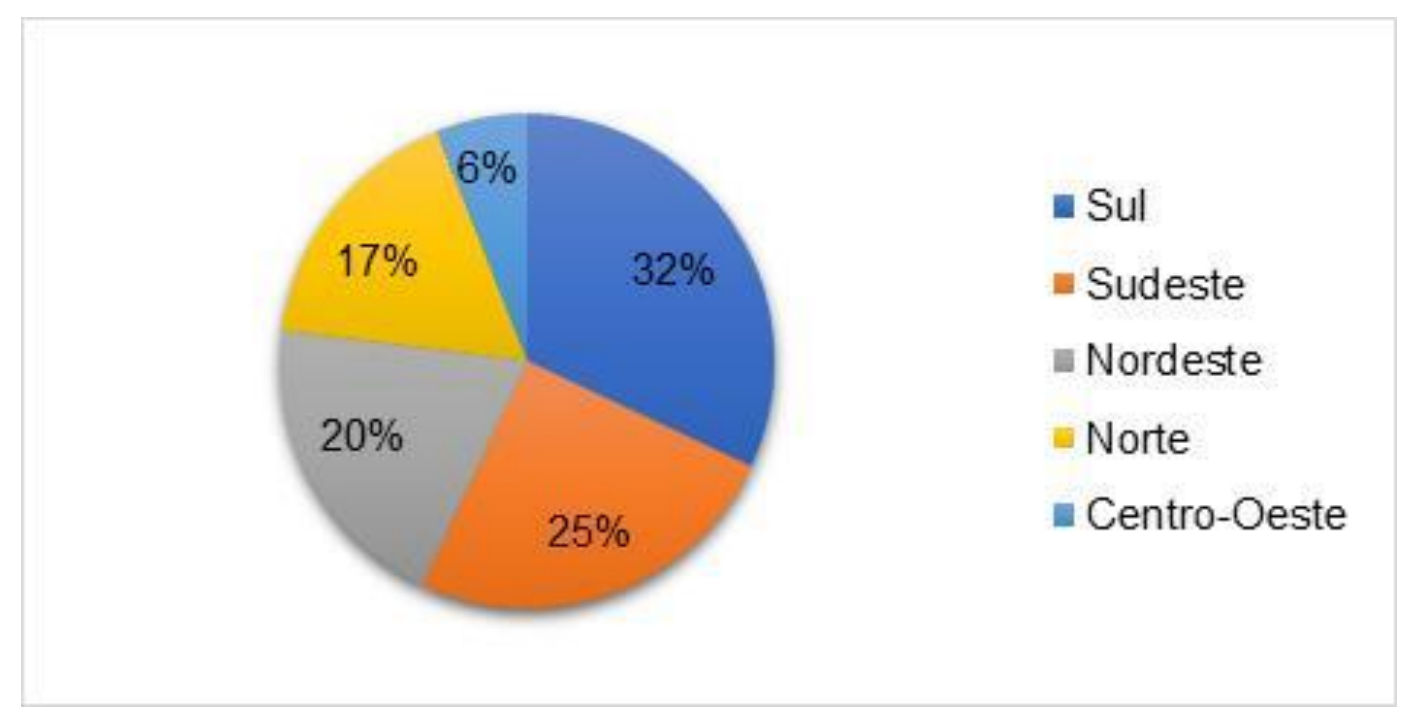

Figura 6: Frequência de distribuição de artigos por regiões geográficas brasileiras sobre Práticas Pedagógicas em Educação Ambiental, entre 2010 a 2017. Fonte: autoria própria.

Quanto aos espaços educativos (formal e não formal) em que foram desenvolvidas as práticas, a maior parte dos trabalhos ocorreu em espaços educativos formais, com 125 artigos. Já os espaços não formais de ensino foram contemplados em 38 trabalhos. A Lei 9.795/99 (BRASIL, 1999) que dispõe sobre a Política Nacional de Educação Ambiental reconhece a Educação Ambiental como um componente essencial e permanente em todo processo educativo, formal e/ou não formal, como orientam os artigos 205 e 225 da Constituição Federal de 1988. Entretanto, observa-se com maior frequência atividades de Educação Ambiental nos espaços formais de educação. Reigota (2017) afirma que "a escola, da creche aos cursos de pósgraduação, é um dos locais privilegiados para realização da educação ambiental' (p.55). Entretanto, segundo Gohn (2006); Pinto e Borges (2015) a inclusão dos espaços não formais em práticas pedagógicas oportunizam a inclusão social e a construção de práticas em uma perspectiva sociointeracionista, tendo como vantagem a aproximação dos estudantes com o cotidiano e sua participação ativa, sendo um espaço atraente que favorece a curiosidade e a aprendizagem eficiente e prazerosa.

$\mathrm{Na}$ Figura 7, é apresentada a distribuição de trabalhos conforme o tipo de público envolvido na atividade prático-pedagógica em Educação Ambiental. Assim, como o esperado, a maior parte das atividades acontece em espaços formais do ensino fundamental, com 72 trabalhos. Reigota (2002) encontrou um panorama semelhante ao revelado nesta pesquisa, predominando trabalhos desenvolvidos no ambiente escolar, com ênfase no ensino fundamental. 


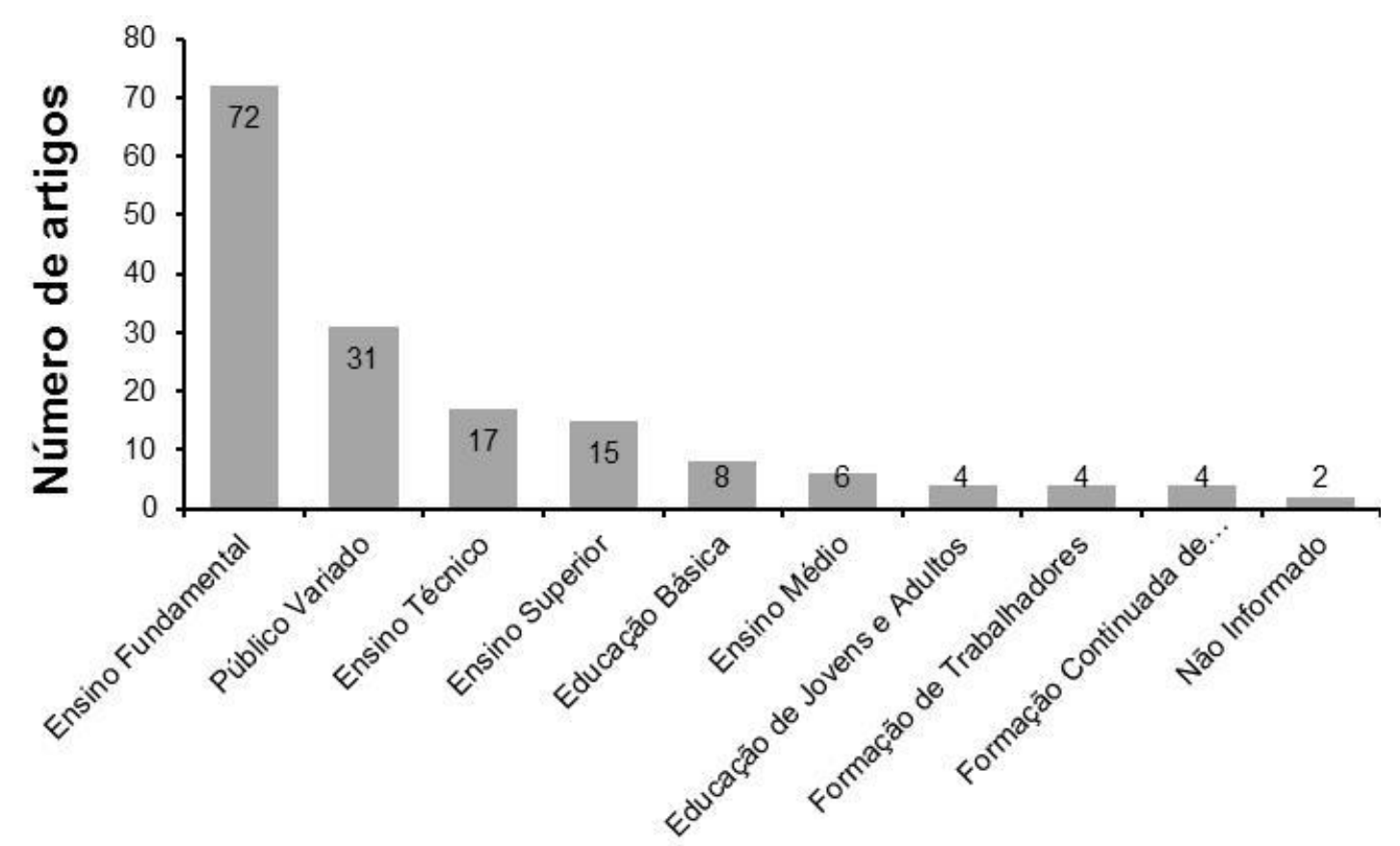

Figura 7: Distribuição da produção de artigos sobre Práticas Pedagógicas em Educação Ambiental de acordo com o tipo de público, entre 2010 a 2017. Fonte: autoria própria.

As Figuras 8 e 9 nos mostram a distribuição e a frequência, em porcentagem, de trabalhos de acordo com a instituição em que ocorreram as atividades práticas de Educação Ambiental. As instituições públicas municipais e estaduais foram as mais privilegiadas, com 56 e 42 trabalhos, respectivamente. Já os trabalhos desenvolvidos fora do ambiente escolar, incluindo unidades de conservação e propriedades rurais, representaram apenas 4 trabalhos.

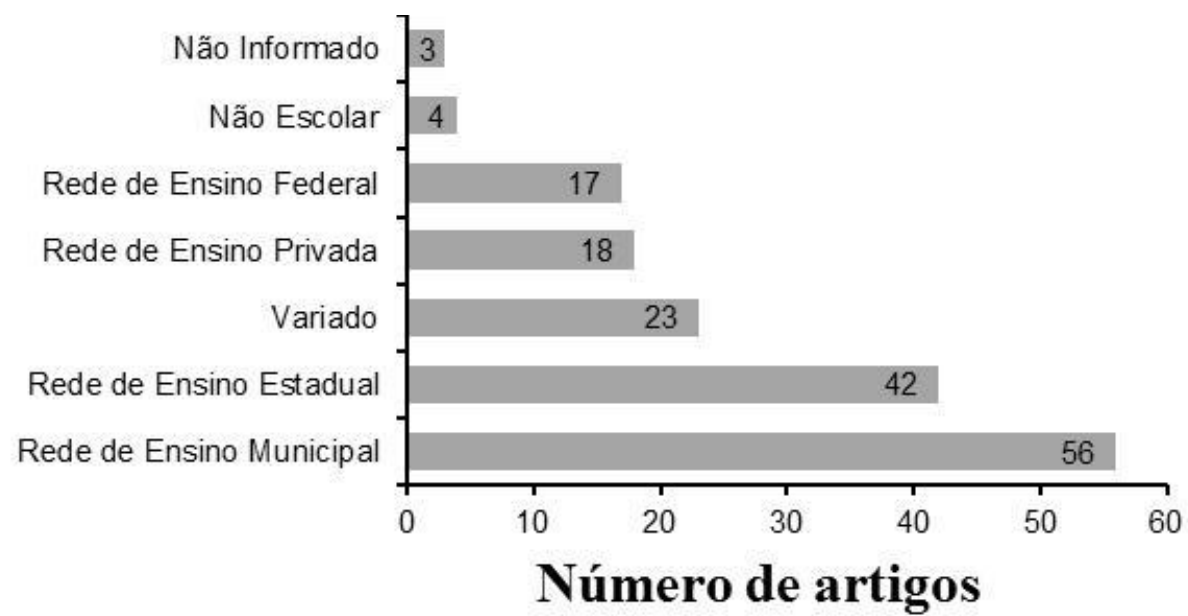

Figura 8: Distribuição da produção de artigos sobre Práticas Pedagógicas em Educação Ambiental de acordo com o tipo de Instituição de Ensino, entre 2010 a 2017.

Fonte: autoria própria. 


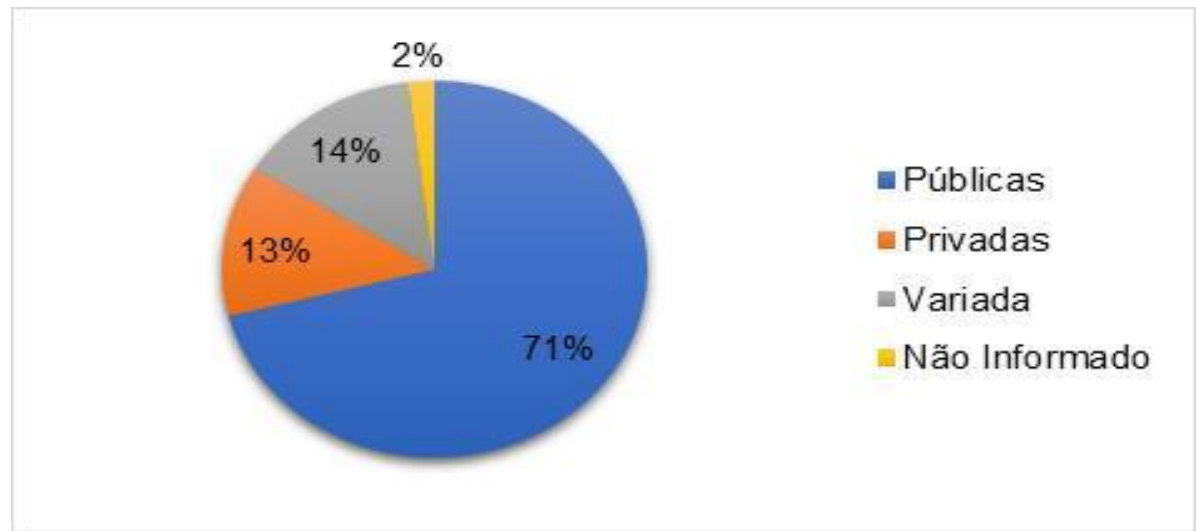

Figura 9: Frequência de distribuição da produção de artigos sobre Práticas Pedagógicas em Educação Ambiental de acordo com o tipo de Instituição de Ensino, entre 2010 a 2017.

Fonte: autoria própria.

A Figura 10 apresenta a distribuição dos tipos de práticas encontrados nos artigos de 2010 a 2017. Esses diferentes tipos de práticas são descritos no quadro 1. A prática mais utilizada pelos autores é o Projeto, conforme descrição no Quadro 1, presente em 102 trabalhos, seguida pelo uso de Atividade Lúdica, em 14 trabalhos. Já as práticas menos utilizadas são as que utilizaram o método do "Tema Gerador", presente em apenas 3 trabalhos e a "Exposição" representado por 1 trabalho. Reigota (2017) também observou que as escolas, atualmente, vêm empregando com maior frequência o método da Pedagogia de Projetos em suas práticas de Educação Ambiental. Método esse que favorece o envolvimento de toda escola para os conhecimentos científicos, popular, étnico e do cotidiano.

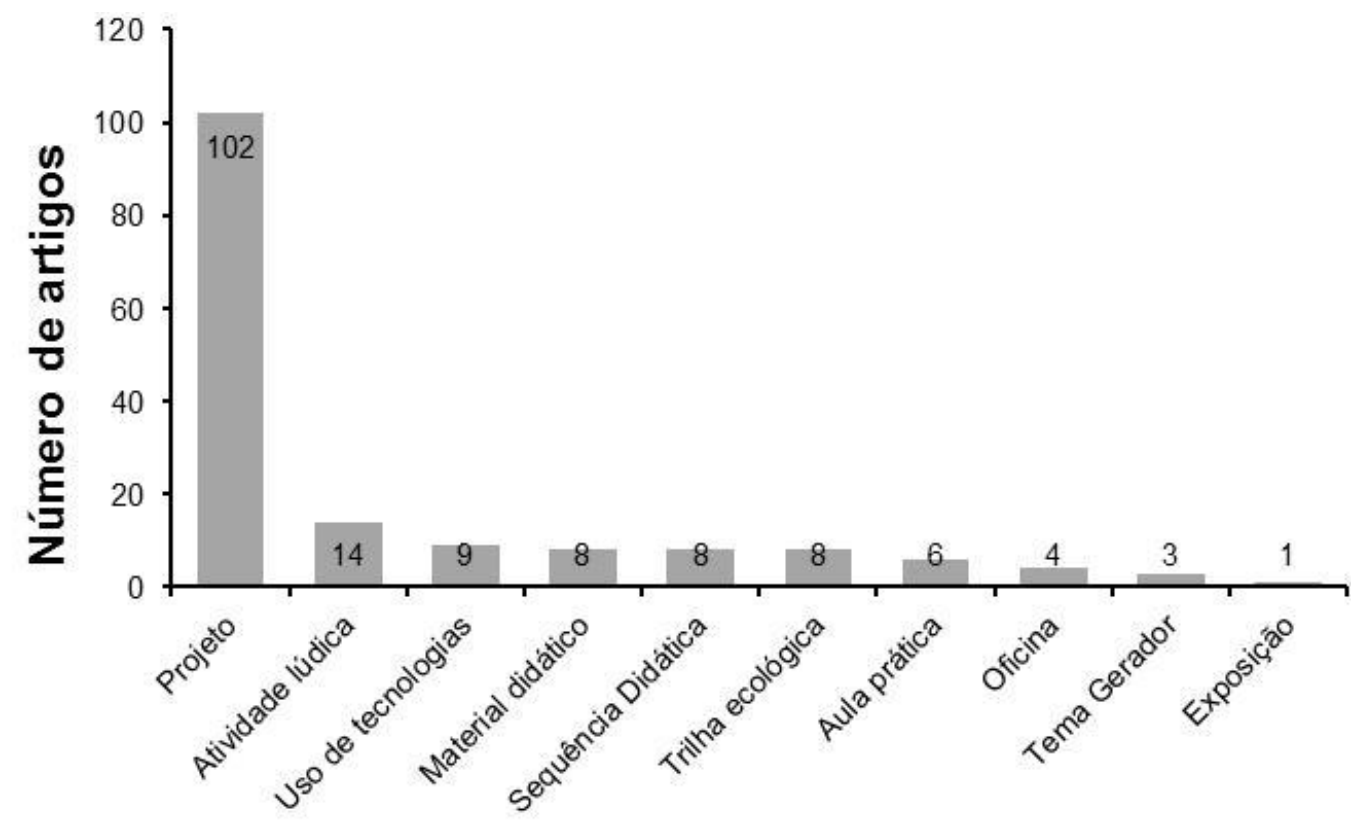

Figura 10: Distribuição da produção de artigos sobre Práticas Pedagógicas em Educação Ambiental de acordo com o tipo de prática, entre 2010 a 2017. Fonte: autoria própria.

Revbea, São Paulo, V. 14, No 1: 09-28, 2019. 
Quadro 1: Tipos de Práticas encontradas nos artigos sobre Práticas Pedagógicas em Educação Ambiental de 2010 a 2017 e suas descrições.

\begin{tabular}{|l|l|}
\hline \multicolumn{1}{|c|}{ TIPO DE } & \multicolumn{1}{|c|}{ DESCRIÇÃO } \\
\hline Oficina & $\begin{array}{l}\text { Atividade que se propõe a ensinar técnicas e habilidades a } \\
\text { partir de conhecimentos teóricos e/ou práticos. }\end{array}$ \\
\hline Tema Gerador & $\begin{array}{l}\text { Atividades embasadas na proposta de tema gerador de Paulo Freire no } \\
\text { seu livro "Pedagogia do Oprimido". Envolve atividades circulares, } \\
\text { programadas em torno de uma temática central, que são desmembradas } \\
\text { em suas diversas complexidades interdisciplinares, partindo do mais geral } \\
\text { ao mais particular. }\end{array}$ \\
\hline Projeto & $\begin{array}{l}\text { Atividades organizadas por equipes interdisciplinares, envolvendo } \\
\text { diversas temáticas e incluem práticas pedagógicas diversificadas como } \\
\text { palestras, oficinas, atividades lúdicas, saídas de campo entre outras. } \\
\text { Geralmente são executadas durante semanas temáticas, feiras escolares } \\
\text { ou ao longo do ano letivo. }\end{array}$ \\
\hline $\begin{array}{l}\text { Sequência } \\
\text { didática }\end{array}$ & $\begin{array}{l}\text { Atividades sequenciais planejadas dentro do programa didático de uma } \\
\text { disciplina. }\end{array}$ \\
\hline $\begin{array}{l}\text { Uso de } \\
\text { tecnologias }\end{array}$ & $\begin{array}{l}\text { Atividades que utilizam recursos tecnológicos, como: vídeos, programas } \\
\text { de computador, fotografias, mapas digitais entre outros. }\end{array}$ \\
\hline Exposição & $\begin{array}{l}\text { Material informativo para divulgação, como: cartazes, banners, fotos e } \\
\text { artesanato. }\end{array}$ \\
\hline Atividade lúdica & $\begin{array}{l}\text { Atividades que aliam o caráter lúdico e divertido à didática, como: jogos, } \\
\text { brincadeiras, teatros e dinâmicas. }\end{array}$ \\
\hline Trilha ecológica & $\begin{array}{l}\text { Visita a locais de apreciação da natureza como unidades de conservação. } \\
\text { São atividades de aula passeio, trilhas interpretativas e atividades de } \\
\text { percepção. }\end{array}$ \\
\hline Material didático & $\begin{array}{l}\text { Produção de material contendo conteúdo disciplinar aliado as } \\
\text { informações de conscientização, conhecimentos sobre meio ambiente e } \\
\text { Educação Ambiental. Incluem apostilas, cartilhas e folder. }\end{array}$ \\
$\begin{array}{l}\text { Plano de aula prática que geralmente envolve aulas em laboratórios e } \\
\text { experimentos nas áreas das ciências da natureza. }\end{array}$ \\
\hline
\end{tabular}

Fonte: autoria própria.

Atividades práticas envolvendo "temas geradores" foram pouco encontradas neste estudo, representando uma dificuldade dos educadores ambientais no desenvolvimento de práticas que utilizem os temas ambientais como geradores (TOZONI-REIS, 2006). Os "temas geradores", uma metodologia de ensino defendida no livro Pedagogia do Oprimido (FREIRE, 2014), evitam uma abordagem conceitual simplificada, fragmentada e mecânica da natureza. Dessa maneira, são valiosos recursos para concretização dos objetivos da Educação Ambiental, pois possibilitam a problematização e uma discussão crítica das contradições vivenciadas pelos sujeitos em suas realidades locais, além de favorecer a construção de conhecimentos socioambientais de maneira transdisciplinar (MÜLLER; TORRES, 2015; PINTO; BORGES, 2015). 
Quanto à autoria das práticas, a Figura 11 revela que a maior parte foi produzida por iniciativa da parceria entre universidades e escolas. São incluídos os pesquisadores, os projetos de extensão universitária e o Programa Institucional de Bolsas de Iniciação à Docência (PIBID), que somados correspondem a $63 \%$ das autorias sobre as práticas.

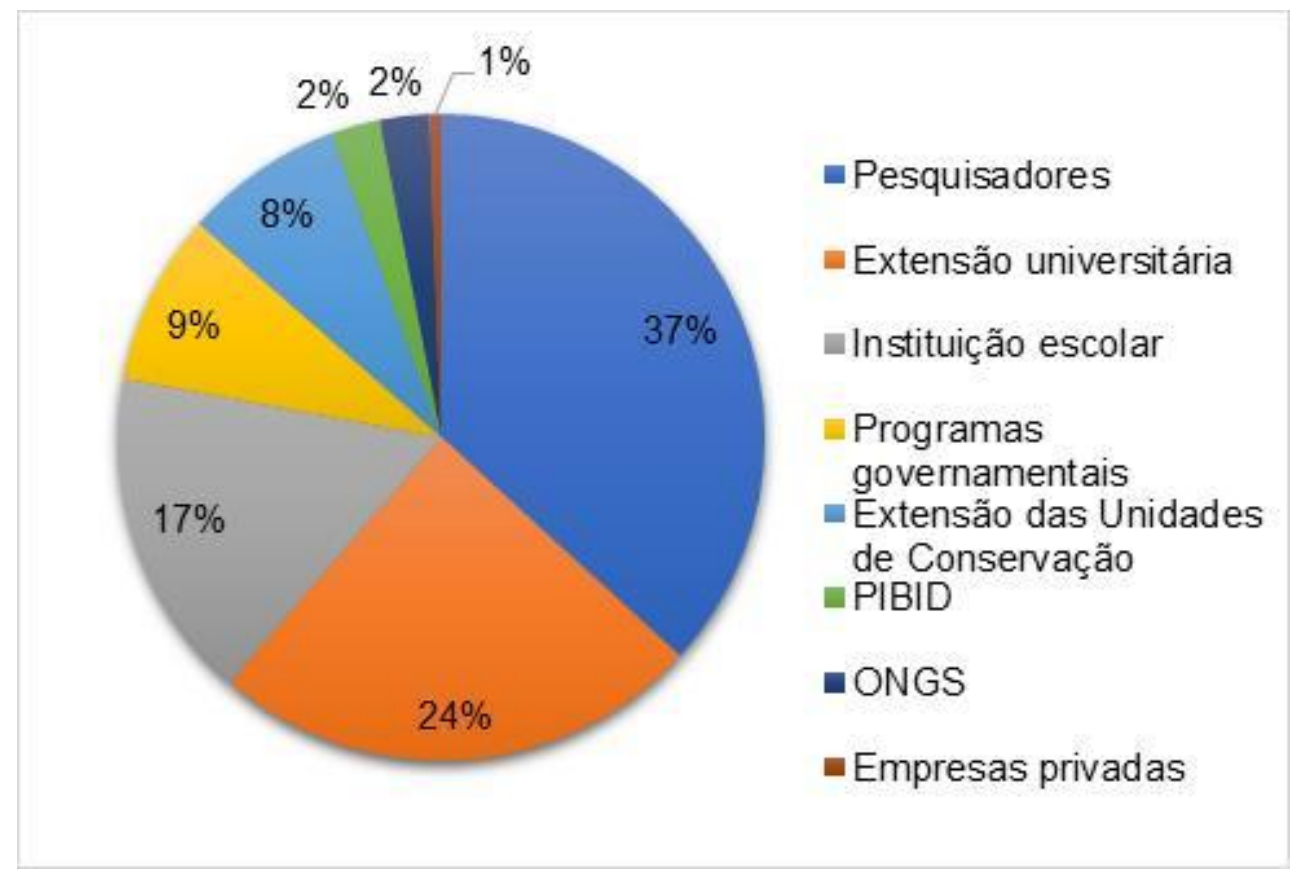

Figura 11: Distribuição da frequência da produção de artigos sobre Práticas Pedagógicas em Educação Ambiental de acordo com a autoria da prática, entre 2010 a 2017.

Fonte: autoria própria.

Em relevância, está a ação dos pesquisadores que correspondem a $37 \%$ das iniciativas de promoção de práticas pedagógicas em Educação Ambiental. Entretanto, estes pesquisadores utilizam o espaço escolar em atividades pontuais, com 0 propósito de investigação e estudos de monografias, dissertações ou teses e após o término de seus trabalhos suas propostas de atividades não permanecem na escola.

Todavia, a maior parte das práticas foi realizada com o objetivo de atuar continuamente nas escolas (Figura 12), por meio dos projetos de extensão universitária (25\%), iniciativa das instituições escolares $(17 \%)$, programas governamentais $(9 \%)$ e do PIBID (2\%), que somados, correspondem a $52 \%$ das autorias das práticas. Segundo Müller e Torres (2015), um dos principais atributos para o desenvolvimento da Educação Ambiental é o caráter permanente, pois as mudanças nos paradigmas dos problemas socioambientais são transformadas de forma lenta e gradativa. 


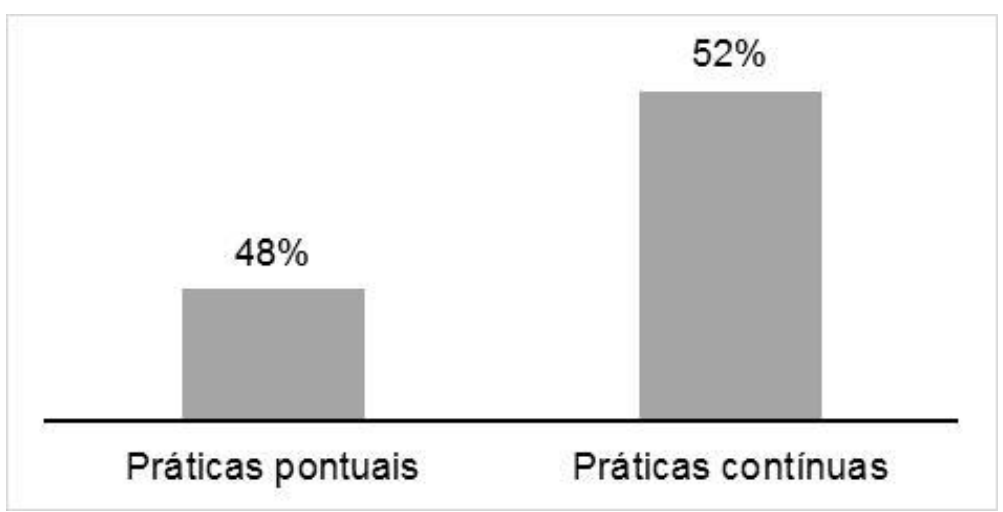

Figura 12: Distribuição da frequência da produção de artigos sobre Práticas Pedagógicas em Educação Ambiental de acordo com a continuidade da prática, entre 2010 a 2017.

Fonte: autoria própria.

Identificaram-se 23 temas ambientais nas práticas pedagógicas, nos artigos, e suas descrições estão dispostas no Quadro 2. As temáticas mais abordadas nas atividades práticas são o tema "Lixo", ou também chamado de resíduos sólidos, termo mais aplicado após a criação da Política Nacional de Resíduos Sólidos, com 24 trabalhos, e, em seguida, o tema "Reciclagem", com 23 trabalhos (Figura 13). O tema "Lixo" é considerado um dos maiores problemas ambientais urbanos da nossa sociedade, e o tema "Reciclagem" surge como uma das principais formas de resolução da problemática. Contudo, segundo Layrargues (2002) trabalhar com essa temática pode gerar uma visão simplista e reducionista sobre os valores da sociedade de consumo e reproduzindo a manutenção da lógica de consumo e de produção.

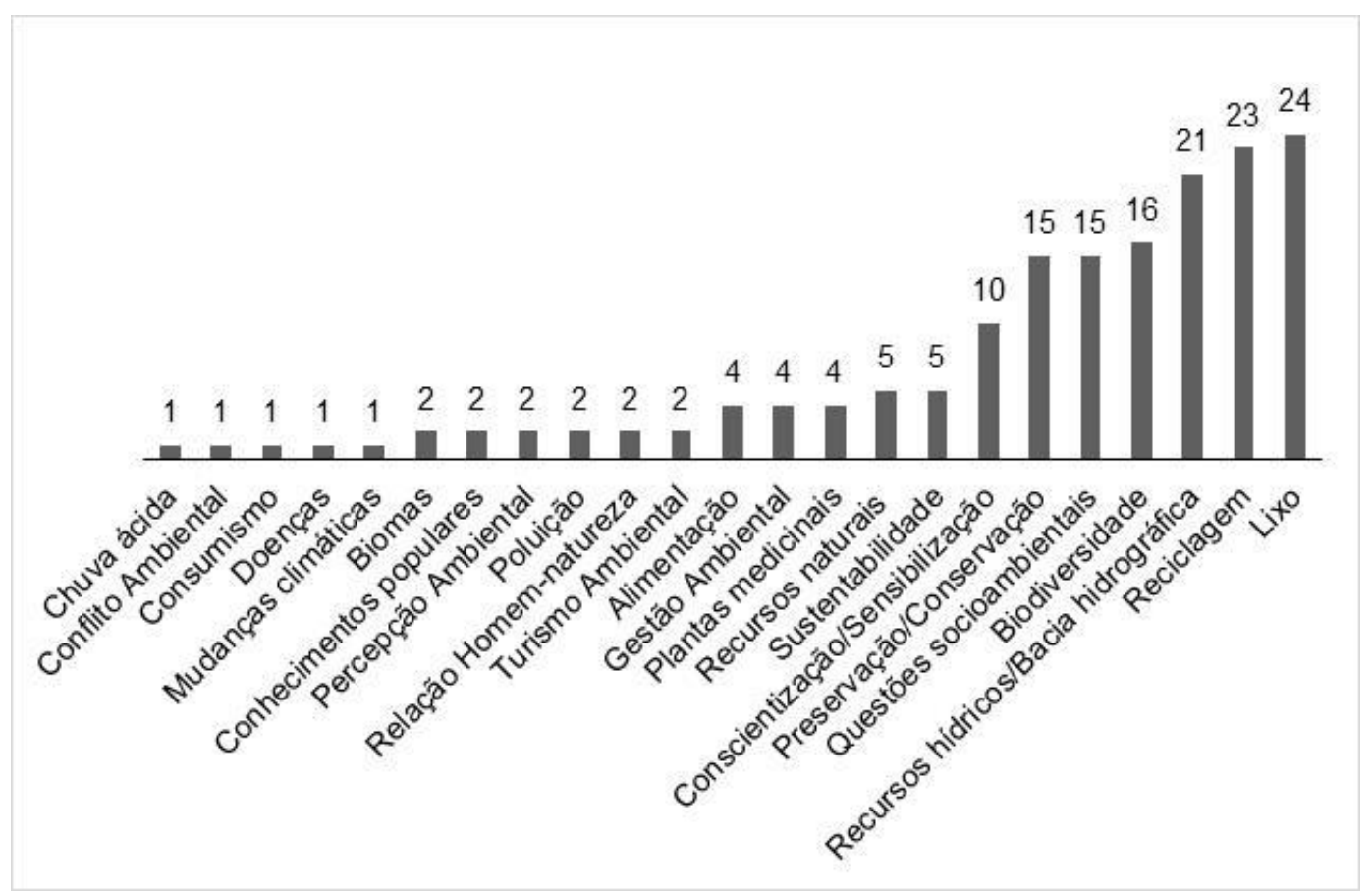

Figura 13: Distribuição da produção de artigos sobre Práticas Pedagógicas em Educação Ambiental de acordo com a temática ambiental, entre 2010 a 2017. Fonte: autoria própria.

Revbea, São Paulo, V. 14, № 1: 09-28, 2019. 
Quadro 2: Tipos de temáticas ambientais encontradas nos artigos sobre Práticas Pedagógicas em Educação Ambiental de 2010 a 2017 e suas descrições.

\begin{tabular}{|c|c|c|}
\hline & $\begin{array}{c}\text { TEMA } \\
\text { AMBIENTAL }\end{array}$ & DESCRIÇÃO \\
\hline 1 & Alimentação & $\begin{array}{l}\text { Trata da promoção da alimentação saudável, discussões sobre } \\
\text { agrotóxicos, produtos orgânicos, sobre hábitos alimentares, } \\
\text { redescoberta sobre os alimentos, suas origens, o contato com a } \\
\text { produção desses alimentos, o cultivo e o contato com a natureza. }\end{array}$ \\
\hline 2 & Biodiversidade & $\begin{array}{l}\text { Aborda as questões ambientais em uma visão ecológica. Enfatiza } \\
\text { sobre a biologia e ecologia de espécies ameaçadas e programas de } \\
\text { conservação da fauna e da flora. }\end{array}$ \\
\hline 3 & Biomas & $\begin{array}{l}\text { Aborda questões sobre preservação e conservação privilegiando um } \\
\text { determinado bioma. }\end{array}$ \\
\hline 4 & Chuva ácida & $\begin{array}{l}\text { Aborda o tema chuva ácida, suas implicações em relação a } \\
\text { transformações químicas no meio ambiente e destruição de } \\
\text { monumentos e florestas. }\end{array}$ \\
\hline 5 & $\begin{array}{l}\text { Conflitos } \\
\text { Ambientais }\end{array}$ & $\begin{array}{l}\text { Aborda as relações de justiça ambiental, identificação de zonas de } \\
\text { conflito, análise socioambiental dos envolvidos, medidas de busca de } \\
\text { direitos e compensações sociais. }\end{array}$ \\
\hline 6 & $\begin{array}{l}\text { Conhecimentos } \\
\text { populares }\end{array}$ & $\begin{array}{l}\text { Trabalha com os conhecimentos populares de moradores antigos, } \\
\text { grupos regionais e comunidades tradicionais para entender a realidade } \\
\text { e divulgar diferentes saberes que se relacionam com os saberes } \\
\text { científicos. }\end{array}$ \\
\hline 7 & $\begin{array}{l}\text { Conscientização } \\
\text { / Sensibilização }\end{array}$ & $\begin{array}{l}\text { Trabalham o contato com a natureza e abordam temas ambientais } \\
\text { variados para trabalhar a importância do meio ambiente. }\end{array}$ \\
\hline 8 & Consumismo & $\begin{array}{l}\text { Debate a questão do consumo como principal causa dos problemas } \\
\text { ambientais. }\end{array}$ \\
\hline 9 & Doenças & $\begin{array}{l}\text { Aborda temas relacionados à saúde pública e o controle de vetores e } \\
\text { doenças, como o combate à dengue. }\end{array}$ \\
\hline 10 & $\begin{array}{l}\text { Gestão } \\
\text { ambiental }\end{array}$ & $\begin{array}{l}\text { Realização de atividades de análise e planejamento da paisagem, } \\
\text { análises socioambientais e de identificação de problemas e produção } \\
\text { de relatórios que possam ser utilizados para reivindicar direitos e } \\
\text { cumprimento de leis. }\end{array}$ \\
\hline 11 & Lixo & $\begin{array}{l}\text { Discute a temática do lixo como grande problema ambiental da } \\
\text { atualidade. Trabalha questões de mudança de comportamento quanto } \\
\text { a melhor deposição dos resíduos. }\end{array}$ \\
\hline 12 & $\begin{array}{l}\text { Mudanças } \\
\text { Climáticas }\end{array}$ & $\begin{array}{l}\text { Discute os problemas que levam a mudança do clima, suas } \\
\text { consequências e medidas de mitigação. }\end{array}$ \\
\hline 13 & $\begin{array}{l}\text { Percepção } \\
\text { Ambiental }\end{array}$ & $\begin{array}{l}\text { Utiliza os conhecimentos sobre percepção, principalmente os advindos } \\
\text { da psicologia ambiental, para desenvolver a construção do } \\
\text { conhecimento sobre o meio ambiente. }\end{array}$ \\
\hline 14 & $\begin{array}{l}\text { Plantas } \\
\text { medicinais }\end{array}$ & $\begin{array}{l}\text { Enfatiza os conhecimentos tradicionais sobre plantas de uso } \\
\text { terapêutico como medida de redução no consumo de remédios } \\
\text { industrializados e como forma de reestabelecer as conexões com o } \\
\text { meio ambiente e o cultivo. }\end{array}$ \\
\hline
\end{tabular}

Continua...

Revbea, São Paulo, V. 14, № 1: 09-28, 2019. 
...continuação.

\begin{tabular}{|c|c|c|}
\hline & $\begin{array}{c}\text { TEMA } \\
\text { AMBIENTAL }\end{array}$ & DESCRIÇÃO \\
\hline 15 & Poluição & $\begin{array}{l}\text { Aborda sobre os diferentes tipos de poluição ambiental (sonora, do ar, } \\
\text { da água, visual e do solo), suas causas, consequências e formas de } \\
\text { mitigação. }\end{array}$ \\
\hline 16 & $\begin{array}{l}\text { Preservação/ } \\
\text { Conservação }\end{array}$ & $\begin{array}{l}\text { Aborda a importância de se preservar e conservar o meio ambiente } \\
\text { para que as gerações futuras possam ter os mesmos direitos a um } \\
\text { ambiente equilibrado. }\end{array}$ \\
\hline 17 & $\begin{array}{l}\text { Questões } \\
\text { socioambientais }\end{array}$ & $\begin{array}{l}\text { Aborda a questão ambiental de forma integrada, trazendo as relações } \\
\text { ser humano-natureza, os problemas e causas da crise ambiental e } \\
\text { societária em uma perspectiva emancipatória e crítica. }\end{array}$ \\
\hline 18 & Reciclagem & $\begin{array}{l}\text { Atividades que abordam o tema reciclagem como medida mitigatória } \\
\text { dos problemas ambientais. }\end{array}$ \\
\hline 19 & $\begin{array}{l}\text { Recursos } \\
\text { hídricos/Bacias } \\
\text { hidrográficas }\end{array}$ & $\begin{array}{l}\text { Apresenta o tema da água como foco das discussões, enfatizando os } \\
\text { principais problemas em áreas urbanas e melhores usos desse } \\
\text { recurso. }\end{array}$ \\
\hline 20 & $\begin{array}{l}\text { Recursos } \\
\text { naturais }\end{array}$ & Discute o uso e conservação de recursos naturais. \\
\hline 21 & $\begin{array}{l}\text { Relação } \\
\text { homem- } \\
\text { natureza }\end{array}$ & $\begin{array}{l}\text { Trabalha a questão de resgate da ideia do ser humano como } \\
\text { pertencente à natureza e de refletir sobre uma melhor relação com ela. }\end{array}$ \\
\hline 22 & Sustentabilidade & $\begin{array}{l}\text { Discussões e/ou implementação de propostas de desenvolvimento } \\
\text { sustentável. }\end{array}$ \\
\hline 23 & $\begin{array}{l}\text { Turismo } \\
\text { Ambiental }\end{array}$ & $\begin{array}{l}\text { Utiliza o turismo como forma de entrar em contato com novos } \\
\text { ambientes e assim desenvolver diferentes sintonias com o meio } \\
\text { ambiente. }\end{array}$ \\
\hline
\end{tabular}

Fonte: autoria própria

Os temas "Conflito Ambiental" e "Consumismo" foram os menos abordados (Figura 13). Embora já considerarmos um ponto positivo o aparecimento destes temas nas discussões, o baixo número de atividades envolvendo esses temas pode ser explicado pela falta de formação em Educação Ambiental Crítica e dificuldade dos educadores em abordar temas que confrontem os sistemas hegemônicos da sociedade.

Em comparação com a pesquisa de Reigota (2002), os temas mais abordados eram os relacionados à ecologia. Já o tema lixo foi apontado de forma mais secundária, diferentemente do exposto nesta pesquisa, em que este tema apresenta um grande destaque. Também em sua pesquisa, temas relacionados às questões socioambientais foram muito pouco representados.

No que diz respeito às macrotendências em Educação Ambiental, cerca de 90 trabalhos (55\%) apresentam a macrotendência "Pragmática", também conhecida como Ecoeficiência, como norteadora da sua atividade prática pedagógica (Figura 14). Estas atividades representam o ambientalismo de resultados, o pragmatismo contemporâneo e o ecologismo de mercado que Revbea, São Paulo, V. 14, № 1: 09-28, 2019. 
decorrem da hegemonia neoliberal instituída no contexto brasileiro desde os anos 1990 (LOUREIRO; LAYRARGUES, 2013). Esse número representa mais da metade da quantidade de artigos em comparação com as vertentes "Crítica", com 37 trabalhos (23\%) e "Conservacionista", com 36 trabalhos $(22 \%)$.

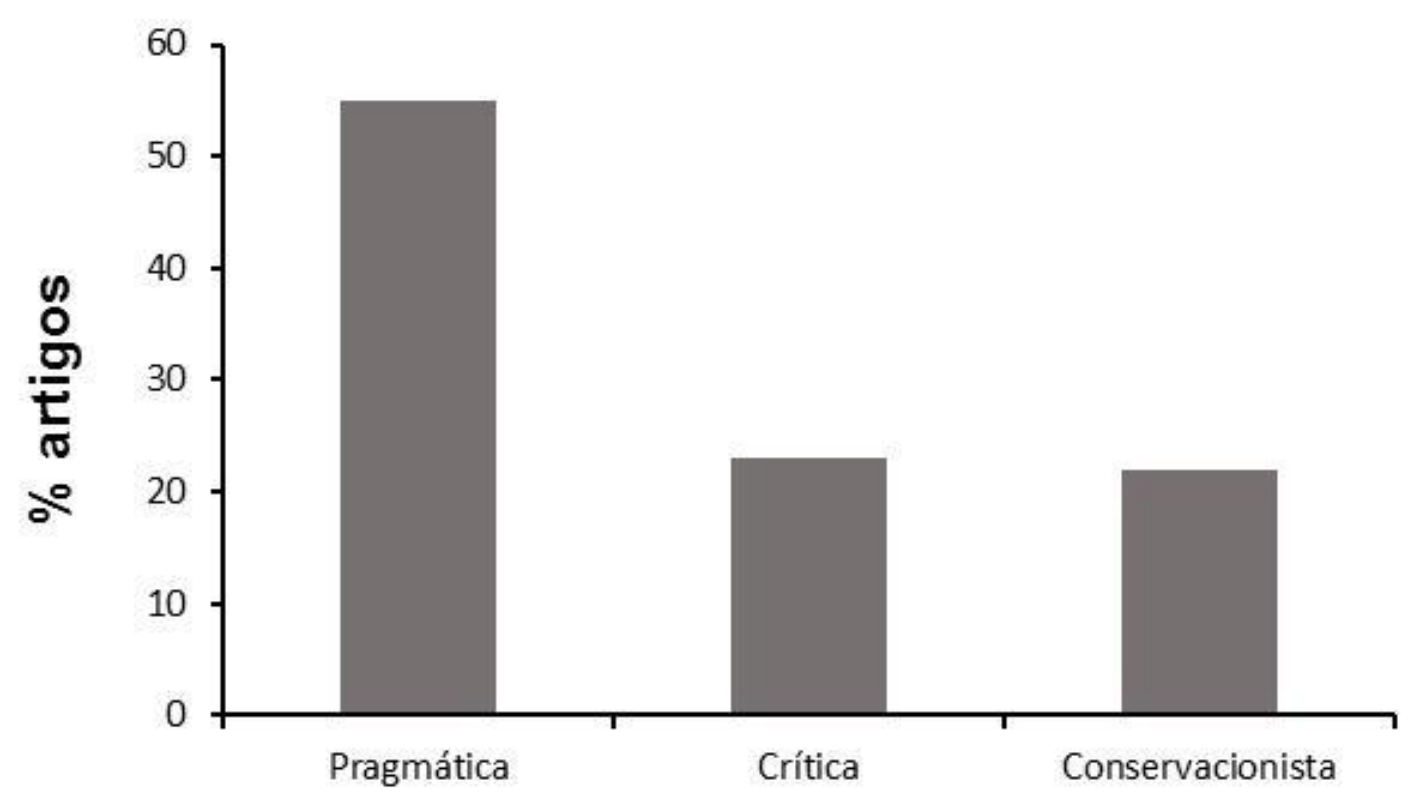

Figura 14: Produção de artigos sobre Práticas Pedagógicas em Educação Ambiental de acordo com as Macrotendências em Educação Ambiental, entre 2010 a 2017. Fonte: autoria própria.

Os resultados da figura 14 convergem com os dados apresentados na figura 13, nos mostrando que à proporção que a maior parte das práticas abordam o tema "Lixo" e a reciclagem, constata-se uma tendência "Pragmática" como sendo a mais abordada nas atividades práticas de Educação Ambiental. Atividades essas que propõem soluções no tratamento de resíduos sólidos, reciclagem e filtros em indústrias. Layrargues e Lima (2011) já haviam observado que a vertente pragmática utilizada tem como base temas urbanoindustriais, em especial a problemática do lixo, no contexto de suas práticas pedagógicas. Em geral, as atividades pedagógicas de cunho pragmático, valorizam o desenvolvimento de mecanismos de compensação para corrigir a 'imperfeição' do sistema produtivo baseado no consumismo, na obsolescência planejada e nos descartáveis. Isso porque esse sistema proporciona um significativo aumento na geração do lixo, o qual necessariamente deve ser reciclado no metabolismo industrial para manter a viabilidade do modelo de acumulação do capital (LOUREIRO; LAYRARGUES, 2013). 


\section{Conclusões}

Acerca das características gerais das práticas, destaca-se nesse estudo que foi possível compreender que a Educação Ambiental brasileira tem se constituído como um campo de atividade científica da área educacional, mas não restrita aos seus limites, e, sim, dialogando e se fazendo presente em diversos outros espaços, estando presente nas diversas áreas do conhecimento, com relevância para as Ciências Humanas, Ciências Biológicas e Ciências Ambientais. Também sendo promovida por diferentes setores da sociedade como a escola, a universidade, as unidades de conservação, ONGS e empresas. Isso demonstrou que a sociedade tem se mostrado sensível às causas ambientais e vem tentando promover ações de Educação Ambiental.

Fazendo alusão às características pedagógicas das práticas, foi possível constatar que, no contexto metodológico e filosófico das práticas, a maioria dos trabalhos estava fundamentada na Pedagogia de Projetos, com vertente pragmática. Apresentavam um ponto de vista em direção à promoção do envolvimento da comunidade escolar, com atividades continuadas, interdisciplinares, além de um uso bastante interessante e proveitoso da parceria universidade e educação básica. Essa estrutura de prática vai ao encontro de alguns objetivos da Educação Ambiental previstos por pesquisadores da área, conferências oficiais e as leis. Contudo, a práxis docente deve estar interligada aos propósitos que servem o modelo de Educação Ambiental praticado, repensando a corrente filosófica que estruturam suas práticas.

Em síntese, o campo da Educação Ambiental apresenta muitos trabalhos teóricos que enriquecem a reflexão epistemológica da área. Assim, com base nos referenciais teóricos, é importante construir práticas didáticopedagógicas que reflitam as discussões por uma Educação Ambiental crítica e emancipatória. É necessário buscar atividades que tragam o efetivo enfrentamento e as mudanças nos paradigmas da sociedade moderna capitalista urbano-industrial, que tanto aliena as pessoas para manutenção de um sistema que está causando o colapso da natureza e a injustiça socioambiental.

\section{Referências}

ALIER. M. O ecologismo dos pobres: conflitos ambientais e linguagens de valoração. 2. ed. São Paulo: Contexto, 2014.

ALVES, S.C.V. Estado da Arte dos Estudos sobre percepção Ambiental no Brasil no Período de 2008 a 2015. Dissertação (Mestrado em Psicologia) Programa de Pós-Graduação em Psicologia da Universidade Federal Rural do Rio de Janeiro, Seropédica, 2016.

BRASIL. Lei 9.795 que institui a Política Nacional de Educação Ambiental. Brasília, DF: 1999. 
BRASIL. Ministério da Educação. Resolução no 2 de 15 de junho de 2012. Estabelece as diretrizes curriculares nacionais para a Educação Ambiental. Conselho Nacional de Educação, Brasília, DF: 2012.

DIAS, G.F. Educação Ambiental: princípios e práticas. São Paulo: Editora Gaia, 2000.

DIAS, G.F.; MARQUES, M.D.; DIAS, S.L. Educação, Educação Ambiental, Percepção Ambiental e Educomunicação. In: DIAS, S.L.; LEAL, A.C.; JUNIOR, S.C. Educação Ambiental: conceitos, metodologia e práticas. São Paulo: Editora ANAP, 2016.

FEITOSA, A. Percepções ambientais planetárias, educação ambiental e sua inserção no Bioma Caatinga. In: ABILIO, F. J. P.; FLORENTINO, H. S. Educação ambiental: da pedagogia dialógica a sustentabilidade no semiárido. João Pessoa: Editora da UFPB, p. 22-36, 2014.

FERREIRA N.S.A. As pesquisas denominadas "estado da arte". Revista Educação \& Sociedade, Campinas, SP, v. 23, p. 257-272, 2002.

FREIRE. P. Pedagogia do oprimido. São Paulo: Editora Paz e Terra, 2014.

GOHN, M.G. Educação não-formal, participação da sociedade civil e estruturas colegiadas nas escolas. Revista Ensaio-Avaliação e Políticas Públicas em Educação, Rio de Janeiro, v. 14, n. 50, p. 11-25, 2006.

LAYRARGUES, P.P. O cinismo da reciclagem: o significado ideológico da reciclagem da lata de alumínio e suas implicações para a educação ambiental. Educação ambiental: repensando o espaço da cidadania. São Paulo: Editora Cortez, v. 3, 2002.

LAYRARGUES, P.P.; LIMA, G.F.C. Mapeando as macro-tendências políticopedagógicas da educação ambiental contemporânea no Brasil. In: Encontro Pesquisa em Educação Ambiental, 6, 2011. Ribeirão Preto. Anais... São Paulo: Revista Pesquisa em Educação Ambiental, 2011.

LIMA, T.C.S.; MIOTO, R.C.T. Procedimentos metodológicos na construção do conhecimento científico: a pesquisa bibliográfica. Revista Katalysis, v. 10, p. 35-45, 2007.

LORENZETTI, L.; DELIZOICOV, D. Educação Ambiental: um olhar sobre Dissertações e Teses. Revista Brasileira de Pesquisa em Educação em Ciências, v. 6, n. 2, p. 1-21, 2006.

LOUREIRO, C.F.B.; LAYRARGUES, P.P. Ecologia política, justiça e educação ambiental crítica: perspectivas de aliança contra-hegemônica. Revista Trabalho, Educação e Saúde, v. 11, n. 1, p. 53-71, 2013.

MANCINI, G.V.; KAWASAKI, C.S. O Estado da Arte da Pesquisa em Educação Ambiental: levantamento e análise de dissertações e teses que relacionam Educação Ambiental e Ecologia. In: ENCONTRO NACIONAL DE PESQUISA EM EDUCAÇÃO EM CIÊNCIAS, 9, 2013. Águas de Lindóia, SP. Anais... São Paulo: Associação Brasileira de Pesquisa em Educação em Ciências (ABRAPEC), v. 14, p. 1-8, 2013.

revista brasileira educação ambiental 
MELLO, S.S.; TRAJBER, R. Vamos Cuidar do Brasil: Conceitos e práticas em educação ambiental na escola. Brasília: Secretaria de Educação Continuada, Alfabetização e Diversidade (Secad) - Ministério da Educação, p. 85, 2007.

MÜLLER, L.; TORRES, J.R. A investigação de temas geradores para a inserção da dimensão ambiental crítico-transformadora na educação escolar. In: EPEA - ENCONTRO PESQUISA EM EDUCAÇÃO AMBIENTAL, 8, 2015, Rio de Janeiro. Anais... São Paulo: Revista Pesquisa em Educação Ambiental, p. 1-13, 2015.

PEDRINI, A.G.; SAITO, C.H. (Org.) Paradigmas metodológicos em educação ambiental. Petrópolis: Editora Vozes, 2014.

PELICIONI, M.C.F.; PHILIPPI JR., A. Educação ambiental e sustentabilidade. Barueri, SP: Editora Manole, pg. 878, 2005.

PEREIRA, P.S.S.; FORTUNATO, I.; LOURENÇO, C. A Educação Ambiental em periódicos brasileiros de ensino de física. Revista Brasileira de Educação Ambiental (RevBEA), v. 11, n. 2, p. 127-138, 2016.

PINTO, B.C.T.; BORGES, J.L.C. Uma atividade de educação ambiental em espaço não formal: potencialidades do uso de bacias hidrográficas. Revista Tempos e Espaços em Educação, p. 109-124, 2015.

REIGOTA, M. El estado del arte de laeducación ambiental en Brasil. Revista Tópicos eneducación ambiental, v. 4, n. 11, p. 49-62, 2002.

REIGOTA, M. $O$ que é educação ambiental. Taubaté, SP: Editora Brasiliense, 2017.

ROMANOWSKI, J.P.; ENS, R.T. As pesquisas denominadas do tipo "estado da arte" em educação. Revista Diálogo Educacional, n. 6, p. 37-50, 2006.

SOARES, M.B.; MACIEL, F.P. Alfabetização no Brasil: o estado do conhecimento. Disponível em: <http://www.mec.inep.gov.br>, 2000. Acesso em: 11 nov. de 2017.

SOUZA, D.C.; NASCIMENTO JR, A.F. A Pesquisa em Educação Ambiental nas dissertações e teses das Pós-graduações no Brasil: $O$ que estudos do tipo "estado da arte" revelam? Revista Gaia Scientia, v. 8, n. 1, 2014.

TOZONI-REIS, M.F.C. Temas ambientais como "temas geradores": contribuições para uma metodologia educativa ambiental crítica, transformadora e emancipatória. Revista Educar, Curitiba, n. 27, p. 93-110, 2006.

VASCO, A.P.; ZAKRZEVSKI, S.B.B. O estado da arte das pesquisas sobre percepção ambiental no Brasil. Revista perspectiva, v. 34 , n. 125, p. 17-28, 2010. 